American Journal of Applied Sciences 5 (7): 876-880, 2008

ISSN 1546-9239

(C) 2008 Science Publications

\title{
Effects of Creative, Educational Drama Activities on Developing Oral Skills in Primary School Children
}

\author{
Abdulhak Halim Ulaş \\ Department of Erzurum, Primary School Education, \\ Faculty of Kazim Karabekir Educational, Ataturk Universty, Turkey
}

\begin{abstract}
A research study was carried out to determine whether native language teaching courses that utilize creative drama activities are more efficient in developing oral communication skills in primary school students than the traditionally applied native language teaching courses. In the present research, the elements of oral communication skills of primary school students were investigated in terms of pronunciation and interpretation skills. The study group consisted of two groups of fourth-year students attending an elementary school in the provincial city-center of Erzurum, Turkey, during the 2006-2007 educational year. A random sampling technique was used to form the experiment $(n=32)$ and control $(n=33)$ groups. An observation form was developed to assess oral communication skills and collect data. The validity of this form was verified by referring it to experts and its reliability was confirmed by seven educators. This measurement tool was applied on the experiment and control groups as both a pre-test and post-test. In concordance with the aim of the study, the traditional method, using a teacher-centered course-book, was implemented in the control group, whereas native language instruction lessons were implemented utilizing drama activities in the experiment group. At the end of this 14 week period, both groups participated in the post-test. Data analysis demonstrated a significant difference between the experiment and control groups oral communication skills. The application of drama activities using native language instruction improved development of pronunciation skills when contrasted with traditional, teacher-centered course-book methods.
\end{abstract}

Key words: Drama in education, oral language development

\section{INTRODUCTION}

The age we live in may be defined as the communication age. Effective communication is considered one of the most important skills that individuals should have. Receptive and expressive language abilities constitute a significant aspect of effective communication in terms of language skills. One of the expressive language elements is speaking skill.

Speaking is the most common and important means of providing communication among human beings. The key to successful communication is speaking nicely, efficiently and articulately, as well as using effective voice projection. Furthermore, speaking is linked to success in life, as it occupies an important position both individually and socially.

As is the case with many basic skills, one of the important periods to improve speaking skill is, incontrovertibly, during primary education. Speaking skills acquired and developed during primary education are significant with regard to both acquisition and permanence. Therefore, it is essential that efficient and effective teaching methods are employed in order to improve speaking skills during primary education.

In our view, a favorable technique in aiding primary school students to acquire and develop oral communication skills is the use of creative and educational drama activities. No matter where this technique is applied, creative drama may be considered a method of learning-a tool for self-expression, as well as art. The scope of creative drama may be briefly explained through six learning principles.

- A student learns meaningful content better than other content.

- Learning occurs as a result of a student's interaction with his environment.

- The more sensory organs a student uses while learning, the greater the retention of the lessons.

- A student learns best by doing and experiencing.

- Effective participation is important in learning emotional conduct.

- Learning becomes easier and more permanent in educational environments where there is more than one stimulus. 
Several scientific investigations have demonstrated that creative, instructional and educational drama activities have positive contributions to the general education process and that these activities improve speaking skills. According to Makita ${ }^{[1]}$ dramatic and role-playing activities are valuable classroom techniques that encourage students to participate actively in the learning process. It is important to note that dramatic activity takes several different forms and that the teacher can provide students with a variety of learning experiences by deploying different methodologies according to individual needs, interests and learning levels. In addition, these role-playing activities enable the teacher to create a supportive, enjoyable classroom environment in which students are encouraged and motivated to effectively learn the target language.

Wessels ${ }^{[2]}$ found that using drama activities helped to bring written materials to life by infusing the lifeless print with feeling, imagination and thought for the learner, who became an active participant in the learning process. Providing students the opportunity to place themselves directly in the learning experience greatly improves their comprehension. It is concluded that drama activities are useful in motivating students, holding their attention and stimulating their creativity.

It is an unignorable fact that creative/educational drama activities have an effect on developing language arts skills, as well as contributing more generally to the education process. In this regard, Maley and Duff ${ }^{[3]}$ explain some characteristics of drama activities that may be considered advantageous in developing language skills. Drama can help the teacher achieve reality in several ways: by making learning the language an enjoyable experience, by setting realistic targets for the students, by creatively slowing down real experiences and by linking the language-learning experience with the student's own life experience. Drama can also create a need to learn the language, either through use of creative tension (situations requiring urgent solutions), or by putting more responsibility on the learner, as opposed to the teacher. In addition, drama allows for activity-centered immersion Genesee ${ }^{[4]}$, which can give language learners optimum exposure to a target language.

In Turkey, at the primary-school level, speaking skills are taught within the scope of native language teaching. Because native language teaching entails students acquiring skills and habits rather than a course of knowledge, language skills are acquired by doing and experiencing. The most efficient way of developing students' understanding and expression skills is to facilitate students to be active and direct them towards practice. As Kavcar ${ }^{[5]}$ noted,

In that case, what is essential in language teachinginstruction is to set into action as many sense organs as possible. Particularly, if the lessons and topics are converted to an experience, then they are perceived and learned so deeply that they are not erased from the memory, they are profoundly assimilated and thus permanent learning can be achieved. Hence, it is the creative/educational drama activities that perform this task most efficiently as a teaching method.

Drama has a significant function especially in specifically improving acquired/improved speaking skill among the basic language skills. Smith ${ }^{[6]}$ noted, Although drama has existed as a potential language teaching tool for hundreds of years it has only been in the last thirty years or so that its applicability as a language learning technique to improve oral skills has come to the forefront. Regarding the point that drama has an important impact on language teaching, Goodwin $^{[7]}$ states, Drama is a particularly effective tool for pronunciation teaching because various components of communicative competence (discourse intonation, pragmatic awareness, nonverbal communication) can be practiced in an integrated way.

There are some secondary elements involved in acquiring oral communication skills; adding efficiency to communication and drama activities facilitates the improvement of these elements. Whitear' ${ }^{[8]}$ approach in this regard is, Speaking is not only about words, structure and pronunciation, but also feelings, motivations and meanings that are valuable benefits for bringing drama to the language learner. Drama techniques and activities to develop communication skills-through fluency, pronunciation, co-operative learning, confidence-building and intercultural awareness-may be added to the above-mentioned elements.

One significant characteristic of the social aspect of oral communication skills is the ability to deliver a speech comfortably and with self-confidence. Drama appears to be the ideal method for students to develop self-confidence. In this regard, Pietro ${ }^{[9]}$ says, Students who are not naturally talkative often appear more willing to join in the discourse when they realize that they are not dominated by a teacher figure. Sam ${ }^{[10]}$ agrees by stating, Drama activities can be used to provide opportunities for the student to be involved actively. The activities involve the student's whole personality and not merely his mental process. 
Am. J. Applied Sci., 5 (7): 876-880, 2008

\section{MATERIALS AND METHODS}

The quasi-experimental design with a pre-test-posttest control group was employed in this research. In this pattern, groups were formed using a random assignment to the experimental and control group. Because a quasiexperimental design was used, no population or sampling selection was made; instead, a working group was identified and the equality of the experimental and control groups created from the working group was dealt with accordingly. The working group involved 10 year old fourth grade students $(\mathrm{N}=65)$ in primary school in the provincial center of Erzurum, Turkey. The working group was divided into an experimental group $(\mathrm{n}=32)$ and a control group $(\mathrm{n}=33)$, designated $4 \mathrm{~A}$ and $4 \mathrm{~B}$, respectively. Group 4A (the experiment group) consisted of 20 females and 13 males. Group 4B (the control group) consisted of 20 females and 13 males. All the participants in the study are ethnic Turks. Group $4 \mathrm{~A}$ was subjected to drama activities in the native language teaching courses and group 4B was subjected to traditional education/instruction curriculum. This application lasted fourteen weeks.

\section{RESULTS AND DISCUSSION}

The data collected were analyzed with SPSS 10.0 and the findings were explained using tables and diagrams. The scores obtained from the pre-test and post-test given to the control and experimental groups, as well as the subsequent means and standard deviation, are presented in Table 1.

Prior to conducting the experiment, a t-test was used to determine if there were differences in the beginning education level (academic performance) of the experimental and control groups. There was no significant difference at the significance level of $p<0.05$ between the experiment and the control groups (Table 2). Based on the apparent pre-experimental equivalence of the groups, it was determined the research study could go forward.

When the pre-test performance means in Table 2 are examined, the mean test score of the experimental group (4A) is 25.09 and the control group (4B) is 24.81 . As a result of this analysis, it was determined that there was no statistically significant difference between the groups. The post-test scores, averages and standard deviations of the experiment and control groups were calculated and a t-test was used to test the significance of the difference between the performance averages of the groups. The results are presented in Table 3 .

The average of post-test mean score of the experiment group (4A) is 39.28 and that of control
Table 1: Average values and standard deviations of students' oral communication skills

\begin{tabular}{lllll}
\hline & METHOD & $\mathrm{n}$ & $\overline{\times}$ & SD \\
\hline Pre-Test & Traditional M. & 33 & 24.81 & 5.9290 \\
& Drama M. & 32 & 25.09 & 5.6189 \\
Post-Test & Traditional M. & 33 & 27.60 & 6.4660 \\
& Drama M. & 32 & 39.28 & 7.9888 \\
\hline
\end{tabular}

Table 2: T-test analysis of students' oral communication skill pretests

\begin{tabular}{llllll}
\hline Groups & $\mathrm{n}$ & $\bar{x}$ & $\mathrm{SD}$ & $\mathrm{T}$ & $\mathrm{p}$ \\
\hline Control G. (4B) & 33 & 24.81 & 5.92 & 0.192 & 0.848 \\
Experiment G.(4A) & 32 & 25.09 & 5.61 & & \\
\hline
\end{tabular}

Table 3: T-test analysis of students' oral communication skills on the post-test

\begin{tabular}{llllll}
\hline Groups & $\mathrm{n}$ & $\overline{\mathrm{x}}$ & $\mathrm{SD}$ & $\mathrm{T}$ & $\mathrm{p}$ \\
\hline Control G. (4B) & 33 & 27.60 & 6.46 & 6.484 & $0.000^{*}$ \\
Experiment G. (4A) & 32 & 39.28 & 7.98 & & \\
\hline *: Significant at $\mathrm{p}<0.001$ & & & &
\end{tabular}

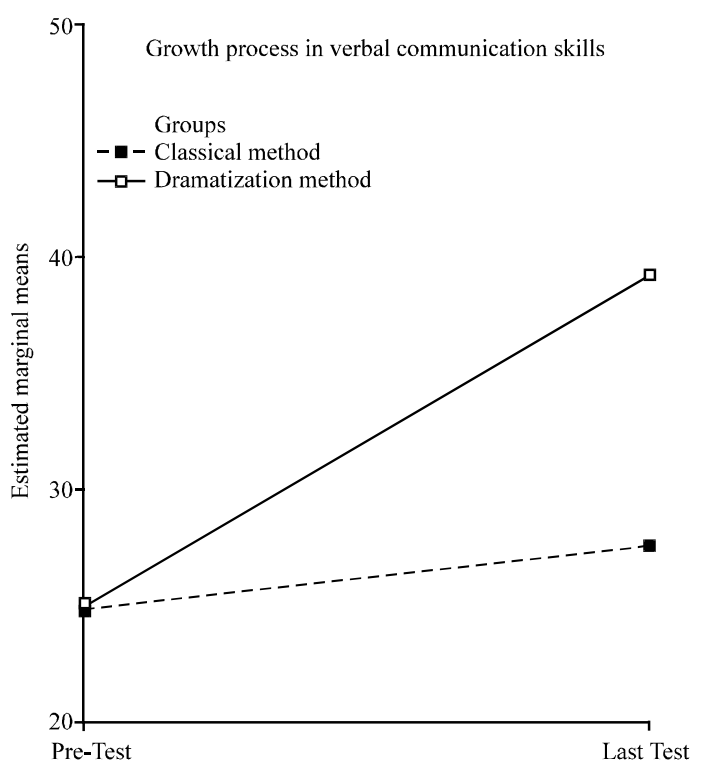

Fig. 1: Growth process in verbal commucation skills

group (4B) is 27.60. A t-test indicated that the group differences was significant at the $\mathrm{p}<0.01$ level. This indicates that there is a very significant difference between the use of traditional education methods to develop oral communication skills and the alternative method which employed drama activities to teach the same skills. This difference is graphicly indicated in Fig. 1.

A t-test was performed to evaluate the difference of the means of the pre- and post-test education levels of the experimental group. A significant difference was found at $\mathrm{p}<0.001$ (Table 4). By comparison, a similar 
Am. J. Applied Sci., 5 (7): 876-880, 2008

Table 4: T-test analysis results comparing the post-test and the pretest points in the experiment group

\begin{tabular}{llllll}
\hline Variables & $\mathrm{n}$ & $\overline{\mathrm{x}}$ & $\mathrm{SD}$ & $\mathrm{T}$ & $\mathrm{p}$ \\
\hline Post-test & 32 & 39.28 & 7.98 & 7.811 & $0.000^{*}$ \\
Pre-test & 32 & 25.09 & 5.61 & & \\
\hline
\end{tabular}

*: Significant at $\mathrm{p}<0.001$

Table 5: T-test analysis results comparing the post-test and the pretest points in the control group

\begin{tabular}{llllll}
\hline Variables & $\mathrm{n}$ & $\overline{\mathrm{x}}$ & $\mathrm{SD}$ & $\mathrm{T}$ & $\mathrm{p}$ \\
\hline Post-test & 33 & 27.60 & 6.46 & 1.9161 & 0.064 \\
Pre-test & 33 & 24.81 & 5.92 & & \\
\hline
\end{tabular}

result was not found in a similar comparison of the preand post-test means of the control group (Table 5).

An experiment was conducted to determine if an alternative education method would result in improved oral communication skills among fourth year students attending an elementary school in the provincial citycenter of Erzurum, Turkey, during the 2006-2007 educational year. The experimental group received fourteen weeks of oral communication education using creative drama activities. The control group retained the traditional oral communication education methods over the same time frame. In terms of developing native language oral communication skills, there was a significant difference in favour of the experimental group when compared with results obtained from traditional education methods applied to the control group.

This significant difference may be explained by the fact that the educational method applied to the experimental group (creative drama activities) has an important function aimed at acquiring oral communication skills. The fact that bare theoretical explanation of a topic or a skill was not considered satisfactory-therefore, it was intensified by practicemade it possible for the experimental treatment to contribute to significant improvement in oral communication skills. Because the studies conducted in the control group consisted of a teacher and coursebook-centered method and was implemented through a plain explanation system without significant active student participation, this method played a limiting role in developing oral communication skills-not a supporting role. This indicates that student-centered experiential learning is essential in native language education lessons.

In regard to pronunciation skills, there is a significant difference in favour of the experimental group and the results obtained from the control group. The skills generally focused on for pronunciation are: the ability to speak in front of crowds comfortably; articulating sounds correctly; not producing unnecessary sounds; not making redundant repetitions; pronouncing sounds according to their task, without swallowing and without confusing them with each other; making eye contact; and speaking in an audible, clear, fluent and understandable tone. In order to improve pronunciation skills, students in the experimental group repeated difficult tongue-twisters; expressed a topic in meaningful sentences despite sound interference; made impromptu speeches and built up face and chin muscles. Additionally, they voiced different characters in various stories and tales, with distinct intonations and stresses. While attempting to have students complete all these exercises, special emphasis was placed on having the sudents' oral expressions become audible and meaningful.

According to the findings obtained from the posttest, the pronunciation skills of the students in the experimental group indicated a significant improvement over the students in the control group. Similar results in interpretation skills were also noted by the researchers. The experimental lesson plan was designed to help students acquire interpretation skills such as the ability to end an incomplete sentence with meaningful fragments, in accordance with the topic of the sentence; to use fewer redundant words; to prefer words suitable for the meaning in sentence construction; to prevent expressions from conflicting with each other; and to prevent unnecessary repetitions in the sentence. In developing these skills, such activities were performed as creating fiction in connection with the pictures and slides; developing a text suitable for a given title; continuing a story after an introduced fragment; fictionalizing new texts within the frame of given key concepts and forming prose and poetry from keywords. Upon evaluation, we concluded that creative/educational drama activities significantly develop oral communication skills (in terms of pronunciation and interpretation).

\section{CONCLUSION}

This study demonstrated that utilization of creative drama activities in oral communication education classes improved the cognitive field abilities of fourth year students significantly when compared to the methods employed for the past twenty-five years.

\section{REFERENCES}

1. Makita, Y., 1995. The Effectiveness of Dramatic/Role-Playing Activities. In: The Japanese Language Classroom. Available at: http:// journals2.iranscience.net:800/mcel.pacificu.edu/mc el.pacificu.edu/aspac/papers/scholars/makita/makit a.htm. 
2. Wessels, C., 1987. Drama. Oxford: Oxford University Press, pp: 41-69.

3. Maley, A. and A. Duff, 1984. Drama Techniques in Language Learning: A Resource Book of Communication Activities for Language Teachers. Cambridge:Cambridge University Press, pp: 63-71.

4. Genesee, F., 1987. Learning Through Two Languages: Studies of Immersion and Bilingual Education. Cambridge. Newbury House, pp: 98-126.

5. Kavcar, C., 1988. Türkçe Öğretiminde Dramatizasyon Yöntemi. Ankara University Press, pp: 37-41.

6. Smith, S.M., 1984. The Theater Arts and The Teaching of Second Languages. Reading, Massachusetts: Addison-Wesley, pp: 75-92.
7. Goodwin, J., 2001. Teaching pronunciation. In M. Celce-Murcia, Teaching English as a second or Foreign Language, 3: 26-45.

8. Whitear, S., 1998. English through drama: A visual/physical approach. The Language Teacher, (4): 43-46.

9. Di Pietro, R.J., 1987. Strategic Interaction: Learning languages through Scenarios. Cambridge. Cambridge University Press, pp: 85-89.

10. Sam, W.Y., 1990. Drama in teaching English as a second language: A communicative approach. The English Teacher, 9: 13-17. 